\title{
SCREW FIXATION IN THE MANAGEMENT OF THE FRACTURED CARPAL SCAPHOID
}

\author{
Roy H. Maudsley, Ascot, and S. C. Chen, London, England \\ From Heatherwood Hospital, Ascot, and Wexham Park Hospital, Slough
}

\begin{abstract}
Although most recent fractures of the carpal scaphoid unite with immobilisation in a well-fitting plaster, some fail to do so within a reasonable time, say three months. Fractures associated with perilunar dislocation are particularly prone to delay. For these, as well as for fractures showing delayed union or non-union, internal fixation provides a speedy return to activity. Over a period of ten years the method advocated by McLaughlin (1954) has been used with minor modifications in a series of patients with various types of fracture. The results are simply reported and some observations made; no attempt has been made at comparison with other methods of treatment. We would, however, like to stress the rapid return to work, which is seldom possible with immobilisation in a cast.
\end{abstract}

TABLE I

Sex and Age of Sixty-two Patients

\begin{tabular}{|c|c|c|c|c|c|c|c|}
\hline \multicolumn{2}{|c|}{ Age (years) } & 11-20 & 21-30 & $31-40$ & 41-50 & $51-60$ & Total \\
\hline Male & . & 13 & 28 & 9 & 7 & 3 & 60 \\
\hline Female & . & - & - & 1 & 1 & - & 2 \\
\hline
\end{tabular}

TABLE II

Type of Fracture in Fifty-six Patients

\begin{tabular}{|l|c|}
\hline \multicolumn{1}{|c|}{ Type } & Number reviewed \\
\hline Recent . . & 22 \\
Delayed union . & 15 \\
Non-union $\cdot$ & 19 \\
Total . & 56 \\
\hline
\end{tabular}

CLINICAL MATERIAL

This series comprised sixty-two consecutive patients treated between 1956 and 1966 by screw fixation. The distribution by age and sex is shown in Table I.

Fifty-six of the patients were available for recent examination. They have been divided into three groups (Table II). "Recent" fractures were those which had occurred within three months of operation. They included undisplaced and displaced fractures and perilunar transscaphoid dislocations. "Delayed union" meant failure to unite within a year of the injury. "Non-union" was the term used when a clear gap was present at the fracture line after more than a year. No patient with non-union was operated upon until splinting had been tried and had failed to relieve symptoms. 


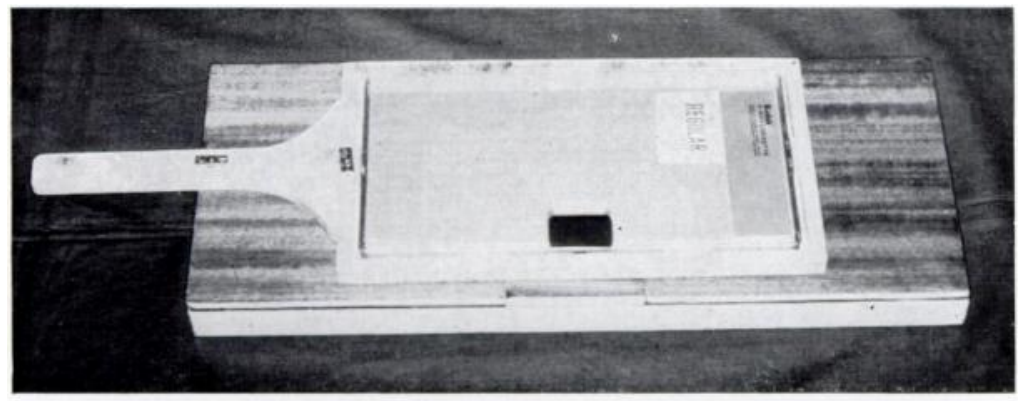

Fig. 1

The special cassette-holder.

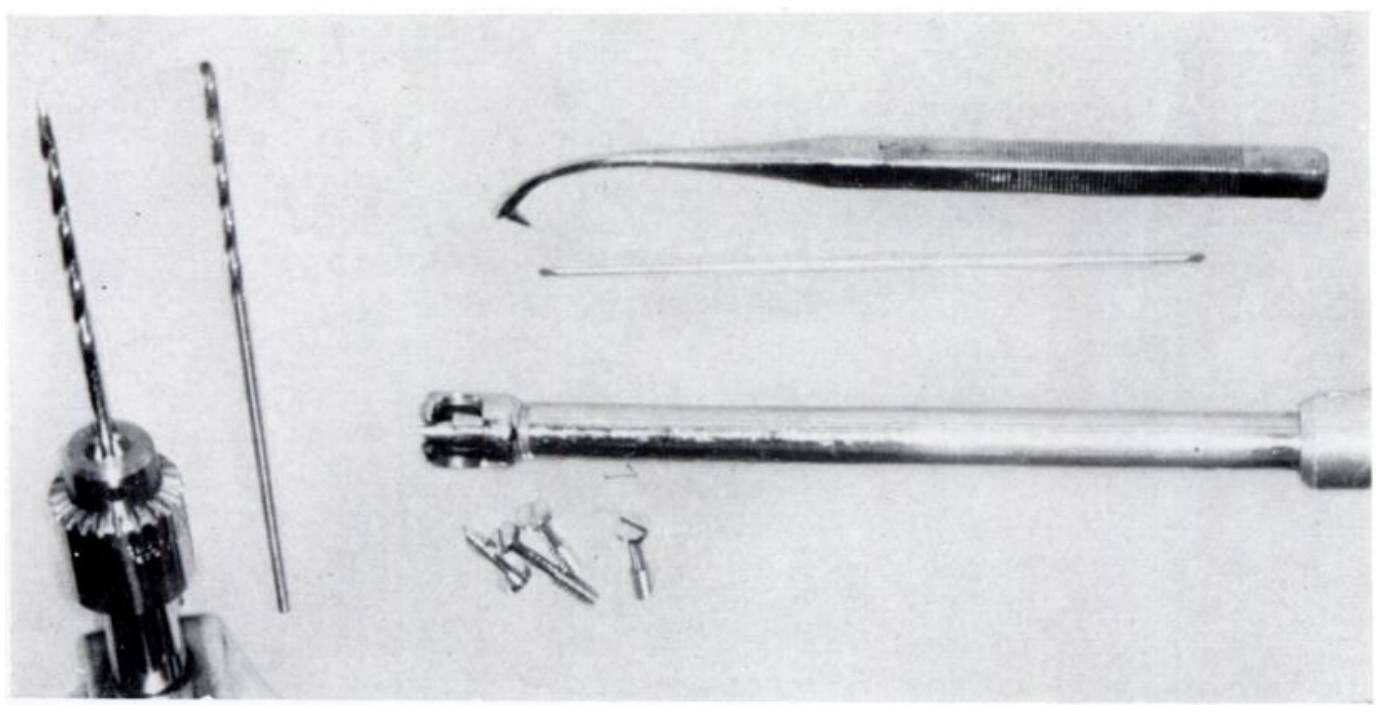

Fig. 2

The special instruments required.

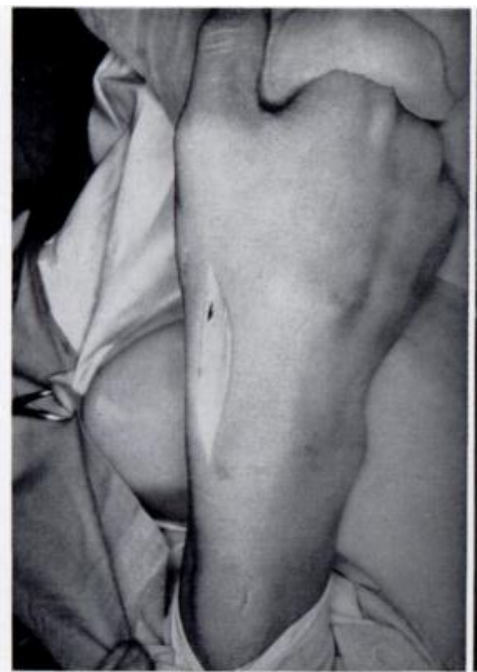

FIG. 3

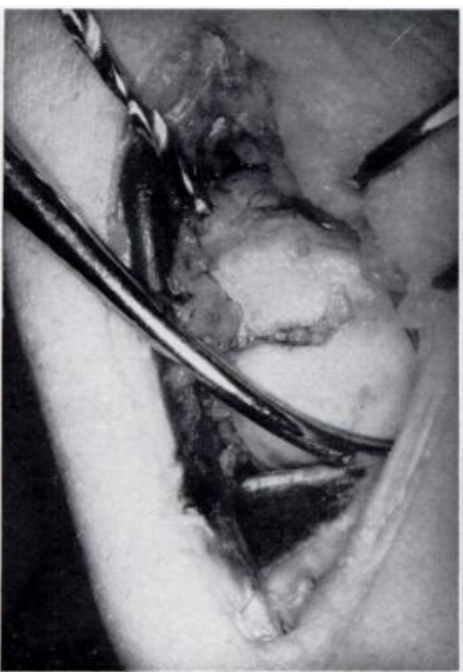

Fig. 4

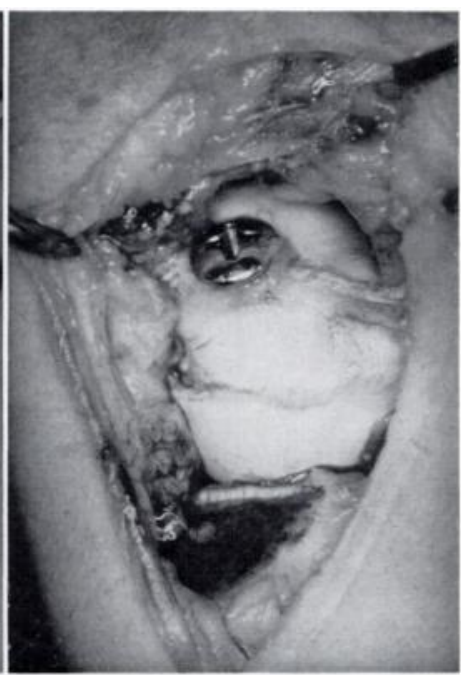

FiG. 5

Figure 3-To show the position of the wrist and the incision. Figure 4-To show the insertion of the drill. The cut surface of radial styloid and the fracture line are well shown. Figure 5-To show the lag screw driven home. The fracture line is now less obvious.

VOL. 54 B, NO. 3, AUGUST 1972 


\section{METHOD OF ASSESSMENT}

The results in each group were analysed under three headings-clinical, economic and radiological - and graded according to merit from excellent (1) to poor (4).

Clinical assessment-An excellent result (Grade 1) was recorded when there was full movement, normal use and no complaints. A good result (Grade 2) indicated mild aching or stiffness. A fair result (Grade 3) implied discomfort and restriction of full use. A poor result (Grade 4) indicated pain and stiffness interfering with normal work. In general, the patient was satisfied when the grading was 1,2 or 3.

Economic assessment-An excellent result (Grade 1) was recorded when there was no limitation of work. A good result (Grade 2) indicated slight limitation of work. A fair result (Grade 3) implied that some work and prolonged use were avoided. A poor result (Grade 4) indicated that the patient had to change his work to a lighter type.

Radiological assessment-An excellent result (Grade 1) was recorded when there were normal appearances and union. A good result (Grade 2) indicated fair appearances and union. A fair result (Grade 3) implied non-union but a good clear outline of the scaphoid. A poor result (Grade 4) indicated non-union and a poor outline, perhaps with some evidence of necrosis. In studying the radiographs we often found that their assessment was inferior to the clinical and economic assessments.

\section{OPERATIVE TECHNIQUE}

Little special equipment is required, but a cassette-holder enabling three radiographs to be taken quickly is a great help.

The holder consists of a tray to hold a standard cassette ten by nine inches (twenty-five by twenty-two and a half centimetres) and a box into which the tray fits so that three separate exposures can be made on the same film (Fig. 1). The box is divided into fifths, of which the middle fifth is not covered with lead. A fifth of the box equals a third of the film in width. The film is advanced a third at a time for each exposure. The handle on the tray is marked to denote the position of the film; this enables three views to be taken quickly.

Only four special instruments are necessary-a scaphoid hook, a screw holder and two drills, one $\frac{7}{64}$ inch (2.7 millimetres) and the other $\frac{9}{64}$ inch (3.5 millimetres) (Fig. 2). Cannulated or non-cannulated lag screws may be used.

Operation-The operation is performed under general anaesthesia using a tourniquet. The wrist is placed over an inverted kidney dish in some ulnar deviation (Fig. 3). A lateral incision five centimetres long is made over the anatomical snuffbox exposing the radial styloid and scaphoid. The cutaneous nerve is usually retracted backwards and the radial artery and vein forwards. Any transverse vessels are divided. As a rule the radial styloid is removed.

The capsule is incised and the radiocarpal joint is inspected. The presence of adhesions or of blood, the line of fracture and the mobility of the fragments are all noted. If the fracture is displaced or mobile, a scaphoid hook is used to compress the proximal fragment against the distal as the screw is being inserted; if the fracture is firm this is not necessary. Curved retractors are used to display and hold the scaphoid. The smaller drill is introduced in the non-articular portion in the long axis of the bone. It is directed backwards and proximally 15 to 20 degrees and obliquely enough not to penetrate the articular surface. The main error is to place the drill too horizontally.

Radiographs of the wrist are taken at this stage in three positions with the hand lying unsupported, firstly, in 45 degrees of supination with radial deviation; secondly, a true lateral view; and thirdly, in 60 degrees of pronation with slight ulnar deviation. These positions, which can be maintained without holding during radiography, give a satisfactory view of the scaphoid and screw. If the position is satisfactory the length of lag screw necessary is determined and the larger drill is inserted into the previous drill hole for half an inch ( 1 centimetre) (Fig. 4). The lag screw is then inserted, with the scaphoid hook used if necessary to hold the 


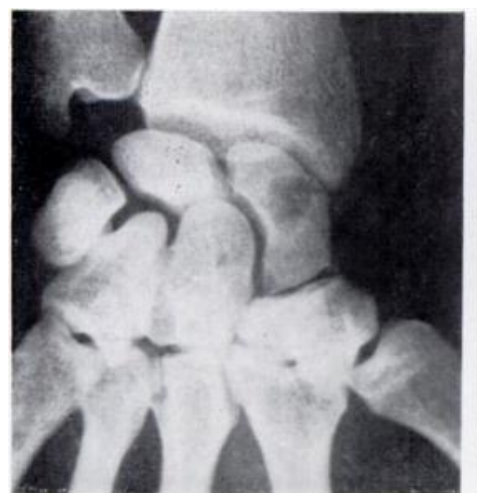

21.4.56

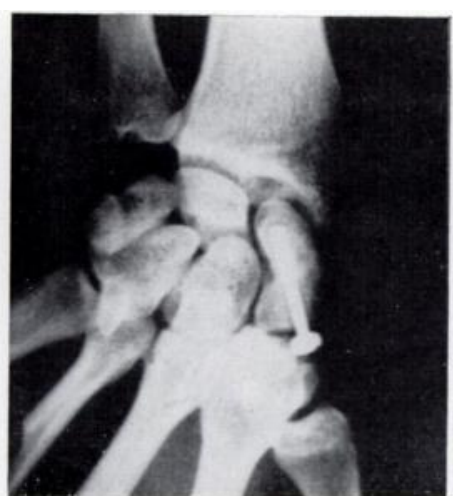

23.4.56

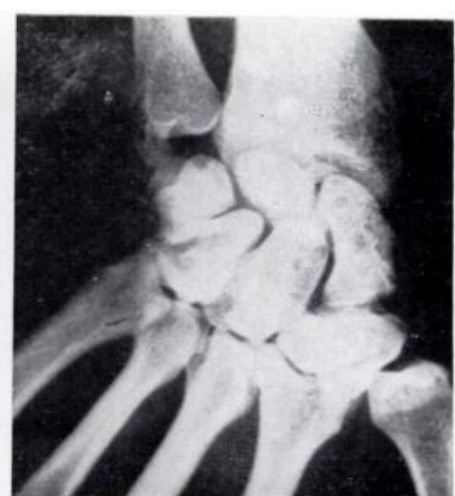

15.10 .56

FIG. 6

Case 1-The radiographs of a clerk aged 24 years who was treated in plaster casts for three months without radiological evidence of union. After operation he remained in hospital one week and immediately returned to work. Six months later he still had some tenderness on the outer side of his wrist; the screw was removed and the symptoms were relieved. Eleven years later he had full movements, no symptoms, and bony union.

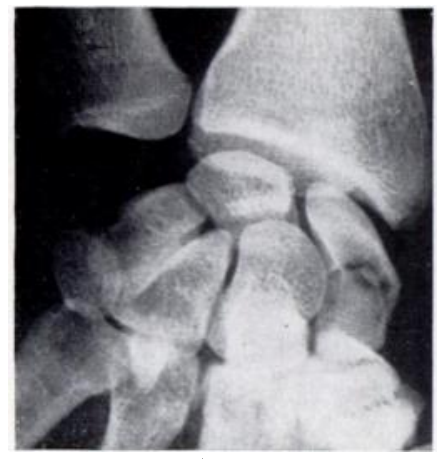

8.6.57

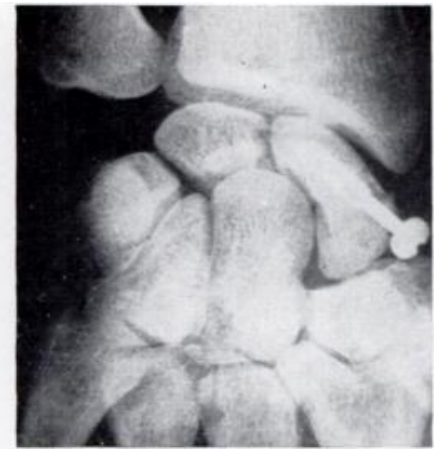

23.7.57

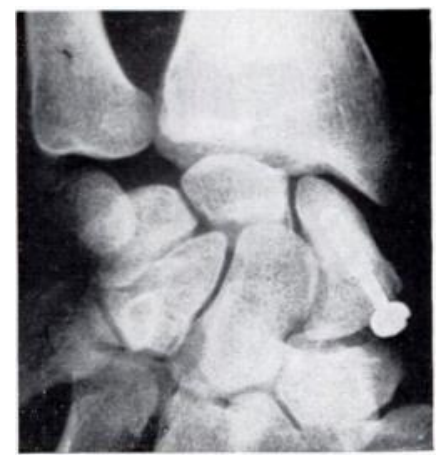

3.1 .67

FIG. 7

Case 7-The radiographs of a mechanic aged 19 years who presented six weeks after injury with a cystic appearance of the fracture zone. Ten days after operation he was discharged and returned to normal work

in six weeks. The fracture united. He had no symptoms or disability at review ten years later.

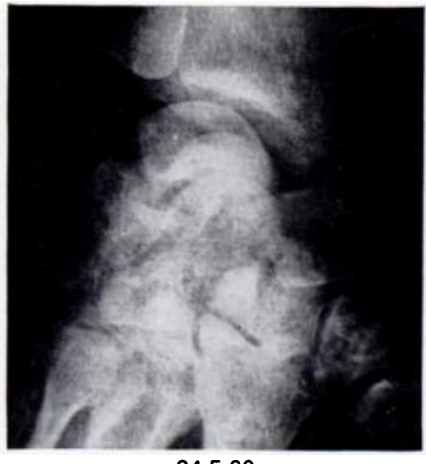

24.5.60

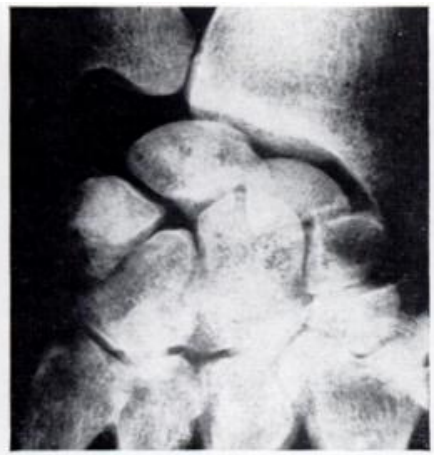

6.7 .60

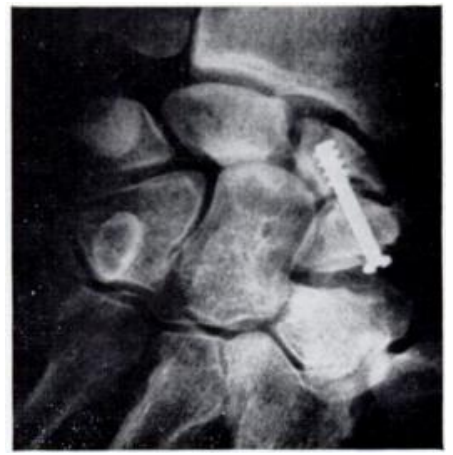

24.5.67

FIG. 8

Case 18-The radiographs of a man aged 30 who sustained a perilunar trans-scaphoid fracture and was referred after six weeks because of possible avascular change in the proximal fragment. He remained in hospital one week and returned to manual work after seven weeks. Seven years later the radiographs showed no evidence of union but he had full movements, normal grip and no complaints. Note that a lag screw was not used in this case.

VOL. 54 B, NO. 3, AUGUST 1972 


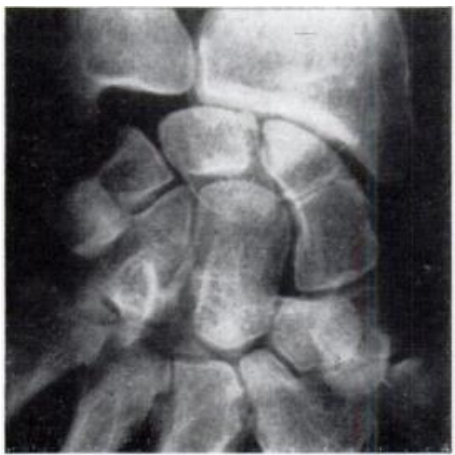

24.3 .66

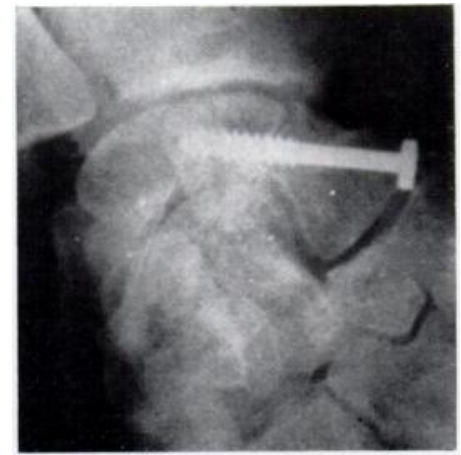

5.5 .66

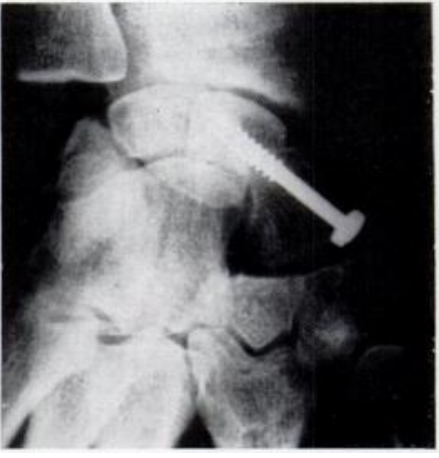

10.11 .66

FIG. 9

Case 37--The radiographs of a mechanic aged 27 years who injured his wrist ten months previously. Plaster casts had been applied, but pain occurred when they were left off. He remained in hospital two days after operation and resumed normal work after a month - his first work for over a year. Bony union occurred and he developed a painless wrist with normal movements.

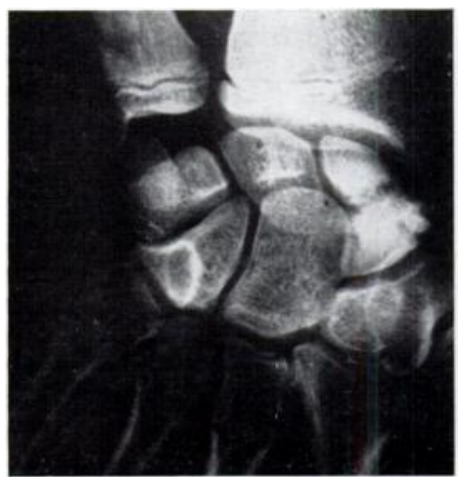

24.3.64

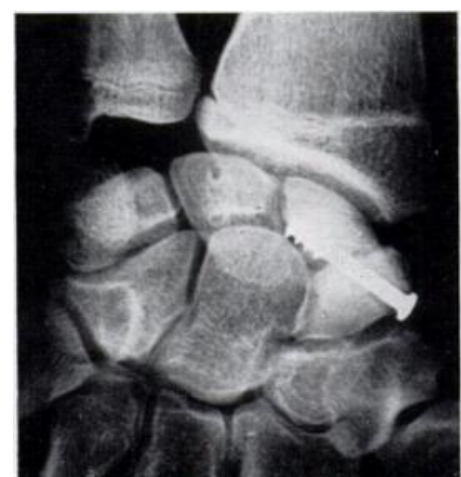

2.10 .64

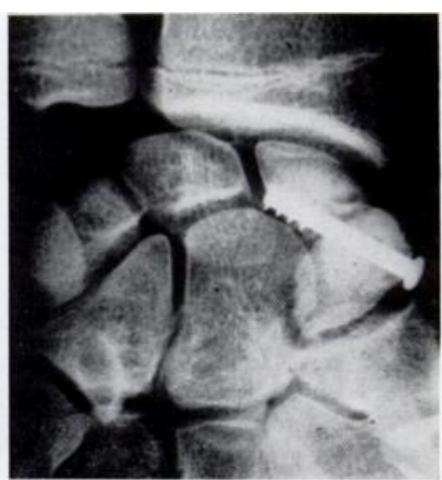

8.6 .65

FIG. 10

Case 54-The radiographs of a young man aged 18 years who had an ununited fracture of the scaphoid for two years and operation was performed for weakness of the wrist and pain unrelieved by splinting. He was in hospital for five days and returned to manual work after a month. One year later he was still at work without symptoms, despite persistent non-union of the fracture.

proximal fragment, and screwed home (Fig. 5). When the screw reaches the proximal fragment it sometimes helps to reverse the screw for a thread or two in order to avoid widening the fracture gap. The position of the screw is very important. It should be along the long axis of the scaphoid, ideally at right angles to the fracture line, and the screw threads should be in the proximal fragment only. Check radiographs are taken at this stage and any necessary adjustment is made. The capsule is closed and the skin sutured. A compression bandage is applied.

Post-operatively, the arm is elevated for twenty-four hours. The stitches are removed on the tenth day. Normally a plaster cast is not necessary and the patient is encouraged to return to light work.

\section{RESULTS}

With this classification the results for each patient in the three groups of fracture are given in Tables III, IV and V. 
Recent fracture (Table VI)-All twenty-two patients were satisfied with their results, and had returned to full work. Nineteen of the fractures united (Figs. 6 and 7). Of the three which failed to unite, two were part of a perilunar trans-scaphoid dislocation (Fig. 8) and the other was a displaced fracture.

TABLE III

Detalls of Twenty-two Cases of Recent Fracture or Fracture-Dislocation

\begin{tabular}{|c|c|c|c|c|c|c|c|}
\hline \multirow{2}{*}{$\begin{array}{c}\text { Case } \\
\text { number }\end{array}$} & \multirow{2}{*}{$\begin{array}{c}\text { Age } \\
\text { (years) }\end{array}$} & \multirow{2}{*}{$\begin{array}{l}\text { Date of } \\
\text { injury }\end{array}$} & \multirow{2}{*}{$\begin{array}{c}\text { Date of } \\
\text { operation }\end{array}$} & \multicolumn{3}{|c|}{ Grading } & \multirow{2}{*}{ Comments } \\
\hline & & & & Clinical & Economic & Radiological & \\
\hline 1 & 24 & 23.1 .56 & 23.4 .56 & 1 & 1 & 1 & Screw removed \\
\hline 2 & 21 & 3.8 .56 & 6.8 .56 & 1 & 1 & 1 & - \\
\hline 3 & 52 & 2.11 .56 & 17.12 .56 & 1 & 1 & 1 & - \\
\hline 4 & 33 & Dec. 56 & 5.2 .57 & 1 & 1 & 1 & - \\
\hline 5 & 25 & 13.4 .57 & 29.4 .57 & 1 & 1 & 1 & - \\
\hline 6 & 26 & 30.4 .57 & 1.5 .57 & 3 & 2 & 3 & $\begin{array}{c}\text { Perilunar } \\
\text { trans-scaphoid } \\
\text { dislocation }\end{array}$ \\
\hline 7 & 19 & 8.6 .57 & 23.7 .57 & 1 & 1 & 1 & - \\
\hline 8 & 20 & 4.7 .57 & 25.7 .57 & 1 & 1 & 1 & - \\
\hline 9 & 23 & 2.8 .57 & 6.8 .57 & 1 & 1 & 1 & - \\
\hline 10 & 28 & 24.8 .57 & 23.9 .57 & 2 & 1 & 3 & - \\
\hline 11 & 37 & Sept. 57 & 31.10 .57 & 1 & 1 & 2 & - \\
\hline 12 & 27 & 20.10 .57 & 26.11 .57 & 1 & 1 & 1 & - \\
\hline 13 & 19 & 20.3 .58 & 3.4 .58 & 1 & 1 & 1 & - \\
\hline 14 & 23 & 30.4 .58 & 3.6 .58 & 1 & 1 & 1 & - \\
\hline 15 & 35 & 25.8 .58 & 28.8 .58 & 1 & 1 & 1 & - \\
\hline 16 & 20 & 5.7 .59 & 13.8 .59 & 1 & 1 & 1 & - \\
\hline 17 & 23 & 30.9 .59 & 22.10 .59 & 1 & 1 & 1 & - \\
\hline 18 & 30 & 24.5 .60 & 12.7 .60 & 1 & 1 & 3 & $\begin{array}{c}\text { Perilunar } \\
\text { trans-scaphoid } \\
\text { dislocation }\end{array}$ \\
\hline 19 & 22 & 24.9 .60 & 29.9 .60 & 2 & 2 & 2 & $\begin{array}{c}\text { Perilunar } \\
\text { trans-scaphoid } \\
\text { dislocation }\end{array}$ \\
\hline 20 & 21 & 1.5 .64 & 14.5 .64 & 1 & 1 & 1 & Screw removed \\
\hline 21 & 50 & 17.6 .66 & 6.7 .66 & 1 & 2 & 2 & - \\
\hline 22 & 31 & 1.10 .66 & 15.11 .66 & 1 & 1 & 1 & - \\
\hline
\end{tabular}

Delayed union (Table VII) - All fifteen patients were satisfied and had returned to normal work. Eight fractures united (Fig. 9), but seven failed to unite, with some discomfort and restriction of full use in five.

Non-union (Table VIII) — Of nineteen patients seventeen were satisfied with the result and

vol. 54 B, NO. 3, AUGUST 1972 
TABLE IV

Details of Fifteen Cases of Fracture with Delayed Union

\begin{tabular}{|c|c|c|c|c|c|c|c|}
\hline \multirow{2}{*}{$\begin{array}{c}\text { Case } \\
\text { number }\end{array}$} & \multirow{2}{*}{$\underset{\left(\begin{array}{c}\text { Age } \\
\text { years })\end{array}\right.}{ }$} & \multirow{2}{*}{$\begin{array}{l}\text { Date of } \\
\text { injury }\end{array}$} & \multirow{2}{*}{$\begin{array}{c}\text { Date of } \\
\text { operation }\end{array}$} & \multicolumn{2}{|r|}{ Grading } & & \multirow{2}{*}{ Comments } \\
\hline & & & & Clinical & Economic & Radiological & \\
\hline 23 & 29 & Sept. 55 & 3.9 .56 & 2 & 1 & 2 & - \\
\hline 24 & 41 & Mar. 56 & 29.10 .56 & 3 & 3 & 4 & - \\
\hline 25 & 28 & ?June 56 & 3.12 .56 & 3 & 2 & 4 & - \\
\hline 26 & 46 & Mar. 57 & 29.8 .57 & 3 & 2 & 3 & - \\
\hline 27 & 23 & Jan. 58 & 4.9.58 & 1 & 1 & 2 & $\begin{array}{l}\text { Screw removed. } \\
\text { Neuroma excised }\end{array}$ \\
\hline 28 & 23 & April 58 & 25.10 .58 & 2 & 1 & 3 & - \\
\hline 29 & 22 & Sept. 59 & 5.5 .60 & 1 & 2 & 2 & - \\
\hline 30 & 20 & Nov. 61 & 11.10 .62 & 1 & 1 & 2 & - \\
\hline 31 & 20 & Nov. 62 & 6.6 .63 & 2 & 1 & 1 & 一 \\
\hline 32 & 27 & Dec. 62 & 6.6 .63 & 1 & 1 & 1 & - \\
\hline 33 & 18 & May 63 & 2.1 .64 & 4 & 3 & 4 & Neuroma excised \\
\hline 34 & 25 & Dec. 63 & 3.3 .64 & 2 & 2 & 3 & - \\
\hline 35 & 18 & Aug. 63 & 1.5 .64 & 2 & 1 & 3 & - \\
\hline 36 & 40 & Mar. 65 & 15.7 .65 & 3 & 2 & 2 & $\begin{array}{l}\text { Female. } \\
\text { Screw removed }\end{array}$ \\
\hline 37 & 27 & July 65 & 5.5 .66 & 1 & 1 & 2 & - \\
\hline
\end{tabular}

resumed normal work. Seventeen of the fractures failed to unite (Fig. 10). One patient required arthrodesis of the wrist.

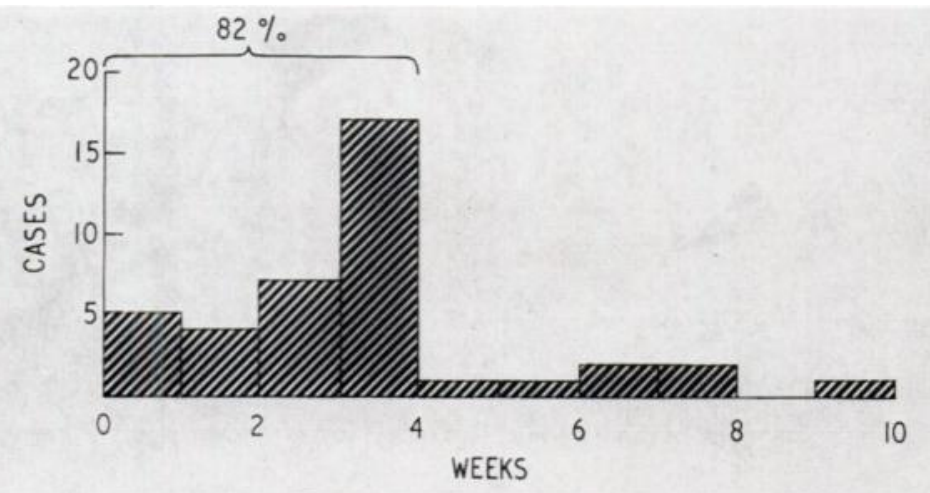

Fig. 11

Interval between operation and return to work.

Return to work-Of all fifty-six patients, 80 per cent had returned to work within one month and 95 per cent within two months, though some at first had restricted duties (Fig. 11). 
TABLE V

Details of Nineteen Cases of Fracture with Non-union

\begin{tabular}{|c|c|c|c|c|c|c|c|}
\hline \multirow{2}{*}{$\begin{array}{c}\text { Case } \\
\text { number }\end{array}$} & \multirow{2}{*}{$\begin{array}{l}\text { Age } \\
\text { (years) }\end{array}$} & \multirow{2}{*}{$\begin{array}{l}\text { Date of } \\
\text { injury }\end{array}$} & \multirow{2}{*}{$\begin{array}{c}\text { Date of } \\
\text { operation }\end{array}$} & \multicolumn{3}{|c|}{ Grading } & \multirow{2}{*}{ Comments } \\
\hline & & & & Clinical & Economic & Radiological & \\
\hline 38 & 45 & 1941 & 5.11 .56 & 2 & 3 & 4 & - \\
\hline 39 & 25 & 1954 & 26.3.57 & 1 & 2 & 2 & - \\
\hline 40 & 60 & 1956 & 8.10 .57 & 2 & 2 & 3 & - \\
\hline 41 & 56 & Not known & 8.10 .57 & 3 & 3 & 4 & Osteoarthrosis \\
\hline 42 & 40 & Mar. 56 & 7.11 .57 & 3 & 3 & 4 & - \\
\hline 43 & 49 & 1952 & 19.11 .57 & 3 & 3 & 4 & - \\
\hline 44 & 17 & 1953 & 6.1 .58 & 2 & 1 & 3 & 一 \\
\hline 45 & 39 & 1943 & 1.9 .58 & 2 & 2 & 4 & - \\
\hline 46 & 34 & 1956 & 18.9.58 & 3 & 2 & 3 & - \\
\hline 47 & 20 & 1957 & 7.5.59 & 2 & 3 & 3 & - \\
\hline 48 & 26 & 1948 & 28.5 .59 & 4 & 4 & 4 & $\begin{array}{l}\text { Screw removed. } \\
\text { Arthrodesis } \\
\text { of wrist }\end{array}$ \\
\hline 49 & 23 & Jan. 59 & 21.7 .60 & 2 & 2 & 3 & - \\
\hline 50 & 21 & 1956 & 2.3.61 & 3 & 1 & 3 & - \\
\hline 51 & 29 & 1960 & 20.8 .63 & 1 & 1 & 2 & - \\
\hline 52 & 44 & 1944 & 1.5 .64 & 2 & 3 & 3 & - \\
\hline 53 & 24 & Nov. 62 & 10.7 .64 & 2 & 1 & 3 & - \\
\hline 54 & 18 & Sept. 62 & 2.10 .64 & 1 & 1 & 3 & - \\
\hline 55 & 41 & Dec. 53 & 12.8 .65 & 2 & 1 & 3 & - \\
\hline 56 & 23 & May 64 & 9.9 .65 & 1 & 2 & 3 & - \\
\hline
\end{tabular}

\section{COMMENTS}

The rationale of this operation is that, by maintaining the fragments securely together, the effects of ligamentous instability are avoided. When a fracture through the waist of the scaphoid occurs there is a strain or rupture of the dorsal carpal ligament, and the proximal row of the carpus may shift in relation to the radius and distal row. An intact scaphoid acts as a bridge between the carpal rows. In the case of fracture the integrity of the wrist may be restored and the ligamentous stress alleviated by fixing the fragments in good position. If they unite, so much the better. If they do not, at least the stress and consequent pain are avoided. This may well be the reason why many ununited fractures that fail to unite after screw fixation nevertheless have satisfactory functional results.

We noted that in some cases of non-union a gap was seen in the radiographs but not at operation; the gap was in fact bridged by dense fibrous tissue. If the bone ends were pulled apart by bone hooks the fibrous union readily gave way. In the earlier cases in the series the fibrous tissue was excised, the bone ends curetted and bone chip grafts from the radial styloid inserted before screwing. This tended to leave some irregularity of the facture line, and in 
later cases only a screw was inserted. When both fragments were found to be freely mobile the grafting procedure was adopted before screwing.

We also noted in cases of recent fracture that although a fracture line was present in the radiograph, even with cyst formation, at operation the cartilage was continuous, though if this was disturbed the bone fragments were mobile. These we likened to a "peanut" fracture. In general this type of case should unite if protected from further injury. It may well be that this cartilaginous shell maintains a functional integrity in the fractured scaphoid, but if broken by a second and possibly minor injury non-union ensues. This could explain the frequent observation that a patient with a minor injury has radiographic evidence of non-union. It also

TABLE VI

The Results in Twenty-two Cases OF RECENT Fracture

\begin{tabular}{|c|c|c|c|c|}
\hline Grade & 1 & 2 & 3 & 4 \\
\hline Clinical & 19 & 2 & 1 & - \\
\hline Economic & 19 & 3 & - & - \\
\hline Radiological & 16 & 3 & 3 & - \\
\hline
\end{tabular}

TABLE VII

The Results in Fifteen Cases of DELAYED UNION

\begin{tabular}{|l|c|c|c|c|}
\hline Grade & 1 & 2 & 3 & 4 \\
\hline Clinical & 5 & 5 & 4 & 1 \\
\hline Economic & 8 & 5 & 2 & - \\
\hline Radiological & 2 & 6 & 4 & 3 \\
\hline
\end{tabular}

TABLE VIII

The Results in Nineteen Cases of NON-UNION

\begin{tabular}{|c|c|c|c|c|}
\hline Grade & 1 & 2 & 3 & 4 \\
\hline Clinical & 4 & 9 & 5 & 1 \\
\hline Economic & 6 & 6 & 6 & 1 \\
\hline Radiological & - & 2 & 11 & 6 \\
\hline
\end{tabular}

suggests that a recent fracture requires protection from further injury because the strength of the fracture site may only be maintained by a cartilaginous shell. A plaster cast might well achieve this protection but in our view the intelligent patient, after a short period of immobilisation in a plaster cast and having been warned against activities with a risk of further injury, can continue with an elastic support. When the circumstances are difficult a plaster cast or screw fixation are the alternatives.

The operation confers the following benefits: 1) early use of the wrist ;2) early return to work; and 3) an opportunity for ligaments to heal and for recent fractures to unite.

In conclusion, we think that screw fixation has a place in the following circumstances: 1) in displaced recent fractures where prolonged immobilisation is likely to prevent return to work ; 2) in perilunar trans-scaphoid dislocations as the method of choice; 3 ) in cases of delayed union where conventional management with splints or casts prevents work; and 4) in cases of non-union without secondary arthrosis when symptoms persist after an adequate period of immobilisation. It is not advocated for simple undisplaced recent fractures, or when there is avascular necrosis of the proximal fragment, or when the proximal fragment is small. 


\section{SUMMARY}

1. A modification of the McLaughlin technique of lag screw fixation of the fractured scaphoid is described.

2. Fifty-six patients operated upon between 1956 and 1966 have been reviewed and their fractures classified under the headings recent, delayed union and non-union.

3. Plaster casts were avoided and early return to work encouraged; 95 per cent did so within two months.

4. Of twenty-two recent fractures, including three perilunar trans-scaphoid dislocations, nineteen united; of fifteen showing delayed union, eight united: and of nineteen cases of non-union, only two united.

5. The function of the wrist in the seventeen cases of persistent non-union stabilised by lag-screw was surprisingly good; only one patient has required arthrodesis to date.

6. The indications and contra-indications for the operation are discussed.

\section{REFERENCE}

MCLaughin, H. L. (1954): Fracture of the Carpal Navicular (Scaphoid) Bone. Journal of Bone and Joint Surgery, 36-A, 765.

vol. 54 B, NO. 3, AUGUST 1972 